\title{
Multi-level disruption of the extrinsic apoptotic pathway mediates resistance of leukemia cells to TNF-related apoptosis-inducing ligand (TRAIL)
}

\author{
S. LEAHOMSCHI ${ }^{1}$, J. MOLINSKY ${ }^{1,2}$, M. KLANOVA ${ }^{1,2}$, L. ANDERA ${ }^{3}$, M. PETERKA ${ }^{3}$, Z. GASOVA ${ }^{4}$, P. KLENER SR. ${ }^{2,4}$, M. TRNENY ${ }^{2,4}$, E. NECAS ${ }^{1}$, \\ T. SIMONOVA ${ }^{1}$, J. ZIVNY ${ }^{1}$, P. KLENER JR. ${ }^{1,2, *}$
}

${ }^{1}$ Institute of Pathological Physiology, $1{ }^{\text {st }}$ Faculty of Medicine, Charles University, Prague, Czech Republic; ${ }^{2} 1^{\text {st }}$ Department of Medicine - Department of Hematology, General University Hospital, Prague, Czech Republic; ${ }^{3}$ Laboratory of Cell Signaling and Apoptosis, Institute of Molecular Genetics, Czech Academy of Sciences, Prague, Czech Republic; ${ }^{4}$ Institute of Hematology and Blood Transfusion, Prague, Czech Republic

*Correspondence: pavel.klener2@vfn.cz

Received October 4, 2012/ Accepted November 14, 2012

\begin{abstract}
Disruption of apoptotic pathways belongs to commonly reported molecular mechanisms that underlie cancer drug resistance. Tumor necrosis factor (TNF)-related apoptosis-inducing ligand (TRAIL, Apo2L) is a cytokine of the TNF family with selective anti-tumor activity and minimal toxicity toward healthy tissues. Primary leukemia cells are, however, largely intrinsically resistant to TRAIL-induced apoptosis. In this study we analyzed molecular differences between TRAIL-resistant K562 cell line and TRAIL-sensitive K562 clones. We demonstrate that TRAIL-sensitive K562 cells differ from the TRAILresistant cell line by cell surface downregulation of TRAIL decoy receptor 1, upregulation of both TRAIL death receptors, enhanced assembly and improved functioning of the death-inducing signaling complex, and increased cytoplasmic protein expression of CASP8 and key proapoptotic BCL2 members BID, BIM, BAD and BAK. The molecular basis of the intrinsic leukemia cell TRAIL resistance thus appears a consequence of the multi-level disruption of the extrinsic apoptotic pathway. The results of this study also suggest that the leukemia TRAIL-resistance is functional, leaving a possibility of overcoming the resistance by preexposure of the leukemia cells to potent TRAIL sensitizers, e.g. BH3-mimetics.
\end{abstract}

Key words: leukemia, drug-resistance, TRAIL, apoptosis, BCL2 family

Intrinsic drug resistance represents one of the main obstacles in cancer therapy. Evading apoptosis through impairment of apoptotic pathways belongs to the commonly reported molecular mechanisms that underlie drug resistance. Tumor necrosis factor (TNF)-related apoptosis-inducing ligand (TRAIL, Apo2L) is a cytokine of the TNF family with selective anti-tumor activity and minimal toxicity toward healthy tissues. TRAIL binds to two death receptors (TRAIL-R1/DR4, TRAIL-R2/DR5) and two decoy receptors (TRAIL-R3/DcR1, TRAIL-R4/DcR4) [1,2]. Ligation of TRAIL death receptors leads to formation of the death-inducing signaling complex (DISC) composed of the TRAIL, death receptors, core adapter protein FADD, initiator caspases CASP8 and CASP10, and FLIP, a competitive inhibitor of CASP8/10. Activated initiator caspases cleave and activate effector caspases CASP3, 6 and 7 , as well as the proapoptotic BCL2 member BID. Truncated BID (tBID) in turn amplifies the proapoptotic signal through the mitochondria [3]. This amplification of the apoptotic signaling from TRAIL death receptors is required in the majority of tumor cells (type II cells). Expression of TRAIL receptors was shown to correlate with prognosis in a variety of tumors, including hematologic malignancies [4-13]. In the last decade, TRAIL-induced apoptosis gained much attention as a potentially targeted anti-cancer therapy [14]. Unfortunately, the anti-tumor activity of both recombinant human TRAIL and anti-TRAIL-death receptor monoclonal antibodies proved to be limited in most reported clinical trials [15-18]. Despite the disappointing clinical results published so far TRAIL might re-emerge as a promising treatment approach in the future, mainly because TRAIL death receptor-targeted therapy possesses favorable toxic profile, it can induce apoptosis in diverse premalignant cell subsets, and it can be largely augmented by pre- or co-treatment with various molecules called TRAIL sensitizers [14,19-26]. Moreover, bioengineered TRAIL molecules or monoclonal antibodies selectively targeting individual TRAIL death receptors with much greater efficacy might demonstrate more potent anti-tumor activity compared to recombinant TRAIL $[27,28]$. 
Primary myeloid leukemia cells are largely intrinsically resistant to TRAIL-induced apoptosis. Several molecular mechanisms responsible for the leukemia TRAIL resistance were reported up to now, including overexpression of TRAIL decoy receptors, overexpression of FLIP or altered expression of apoptosis regulators including BCL2 family members, heat-shock proteins or inhibitor of apoptosis (IAP) proteins [29-37].

In the present study we analyzed the molecular nature of two TRAIL-sensitive K562 clones derived by limiting dilutions from the original TRAIL-resistant K562 cell line. We demonstrated that the TRAIL-sensitive clones differed from the TRAIL-resistant cell line by decreased expression of TRAIL decoy receptor 1, increased expression of both TRAIL death receptors, increased assembly and enhanced functioning of the DISC, and increased cytoplasmic expression of CASP8 and key proapoptotic BCL2 members BID, BIM, BAD and BAK. The molecular basis of leukemia cell TRAIL resistance thus appears a consequence of a multi-level disruption of the extrinsic apoptotic pathway.

\section{Materials and methods}

Cell culture. K-562 cell line was cultured in Iscove's modified Dulbecco's medium (IMDM) supplemented with $10 \%$ fetal bovine serum (FBS) and 1\% penicillin/streptomycin. Peripheral blood samples were collected from patients with de novo diagnosed acute myeloid leukemia (AML, $\mathrm{n}=5$ ) and chronic myeloid leukemia (CML, $\mathrm{n}=5$ ) before therapy after obtaining informed consent according to the Declaration of Helsinki. Mononuclear cells were isolated by Ficoll-Paque (GE Healthcare) density-gradient centrifugation and cultured in IMDM supplemented with 30\% FBS.

Establishment of TRAIL-sensitive cell clones. TRAILsensitive K562 clones were established by limiting dilution from the original TRAIL-resistant K562 cells. K562 cells were diluted to a final concentration of 5 cells per $1 \mathrm{ml}$, distributed onto 96-well plates (100uL per well) and examined under light microscope. Only wells that contained a single cell were used for clone selection. In 14 days the wells with grown K562 clones were split into two wells. While the former well of each K562 clone was exposed to $1000 \mathrm{ng} / \mathrm{mL}$ TRAIL, the latter well was maintained in fresh medium. The percentage of apoptotic cells was measured after 24 hours. Two clones with the highest sensitivity to TRAIL (designated S1, S2) were expanded and used in further experiments described in detail in this current report.

Flow cytometry and detection of apoptosis. Cell surface expression of TRAIL receptors was analyzed by flow cytometry (FACS Canto, Becton Dickinson, California, USA) using primary anti-TRAIL receptor antibodies (R\&D Systems, Minnesota, USA) and secondary PE-conjugated antibodies (Jackson Immunoresearch Laboratories Inc., USA). Apoptosis was measured by flow cytometry using Annexin-V-FITC (Apronex Biotechnologies, Czech Republic) staining. The percentage of apoptotic cells was evaluated using the DIVA software.

Cell proliferation assay. Cells were distributed onto 96well plate (5.000 cells per well) on day 1 . On day 2 increasing concentrations of cytotoxic drugs imatinib, etoposide, doxorubicin, cytarabine, and bortezomib were added to particular wells. Cell proliferation was measured in triplicates using WST-8 Cell Proliferation Assay Kit (Cayman Chemical Company, Ann Arbor, MI, USA) according to the manufacturer's protocol.

DISC precipitation. Cell lysates for immunoprecipitation were prepared from $5 \times 10^{8}$ cells. Cells were precooled prior the addition of biotinylated TRAIL (final concentration 1000 $\mathrm{ng} / \mathrm{ml}$ ). After 15 minute incubation on ice the cells were divided into three equal fractions and quickly warmed to $37^{\circ} \mathrm{C}$. Each fraction was incubated at $37^{\circ} \mathrm{C}$ and analyzed at 0,10 and 30 minutes after warming (i.e. 0 minutes $=$ precipitation after 15 minute exposure to biotinylated TRAIL on ice). Cells were lyzed, and protein content of each sample was assessed using Bradford method. After equilibration of protein content, streptavidin-agarose beads were added to each sample and precipitated in cold room at $4^{\circ} \mathrm{C}$ for one hour. Beads were then separated by centrifugation and washed $5 \mathrm{x}$. Finally, protein complexes were eluted by incubating samples in a heating block at $95^{\circ} \mathrm{C}$ for 15 minutes and agarose beads were removed by centrifugation. Protein precipitates were used for subsequent immunoblotting.

Western blot analysis. Cell lysates were resolved by electrophoresis using Novex NuPAGE ${ }^{\circ} 10 \%$ Bis-Tris Mini Gels (Life Technologies ${ }^{\mathrm{TM}}$, Carlsbad, CA, USA) and transferred to PVDF membranes using iBlot Dry Blotting System (Life Technologies ${ }^{\mathrm{TM}}$, Carlsbad, CA, USA). Blocking of non-specific binding sites was performed by incubation in $0.1 \%$ PBS-Tween 20 and fat-free dry milk (5\%). Membranes were incubated with specific primary antibody overnight at $4^{\circ} \mathrm{C}$, followed by washing in $\mathrm{PBS}$ and incubation with HRP-conjugated secondary antibody at room temperature for 1 hour. Obtained immunoblots were developed by the enhanced chemiluminescence (ECL) reagent kit (Santa Cruz Biotechnology, Inc., Santa Cruz, CA, USA) according to the manufacturer's protocol.

Primary antibodies used in this study were as follows (with dilutions used in the experiments): Beta-actin (I19) Santa Cruz, 43kDa, goat (1:1000); Caspase 2 (C20), Santa Cruz, 51kDa, rabbit (1:200); Caspase 3 (31A1067) Alexis, $32 \mathrm{kDa}$, mouse (1:1000); Caspase 8 (12F5), Alexis, $55 / 54 \mathrm{kDa}$, mouse (1:1000); Caspase 9 (5B4), MBL, $45 / 37 / 35 \mathrm{kDa}$, mouse (1:500); Caspase 10 (4C1), MBL, 58/57kDa, mouse (1:500); BAD (C7), Santa Cruz, 25kDa, mouse (1:500); BAK (3814S), Cell Signaling, 25kDa, rabbit (1:1000); BID (5C9) Santa Cruz, $22 \mathrm{kDa}$, mouse (1:200); XIAP (2F1), MBL, $55 \mathrm{kDa}$, mouse (1:1000); BCL-XL (M125), Santa Cruz, $30 / 18 \mathrm{kDa}$, rabbit (1:200); BIM (H191), Santa Cruz, 24/21/19kDa, rabbit (1:200); MCL-1 (3035-100), BioVision, 43/37kDa, rabbit (1:200); BAX (610983), BD, $21 \mathrm{kDa}$, mouse (1:250); BCL-2 (610539), BD, 

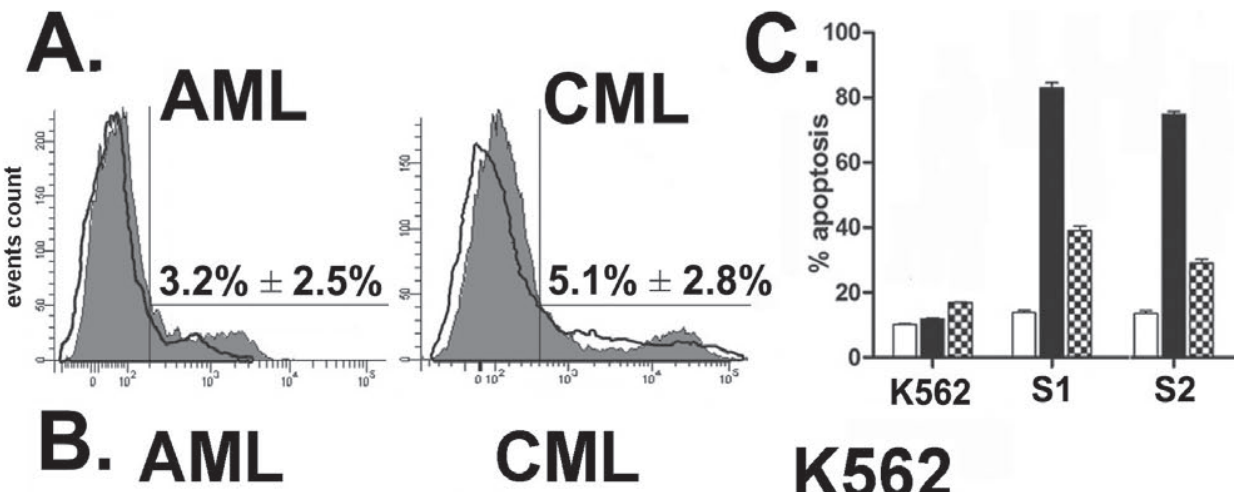

K562
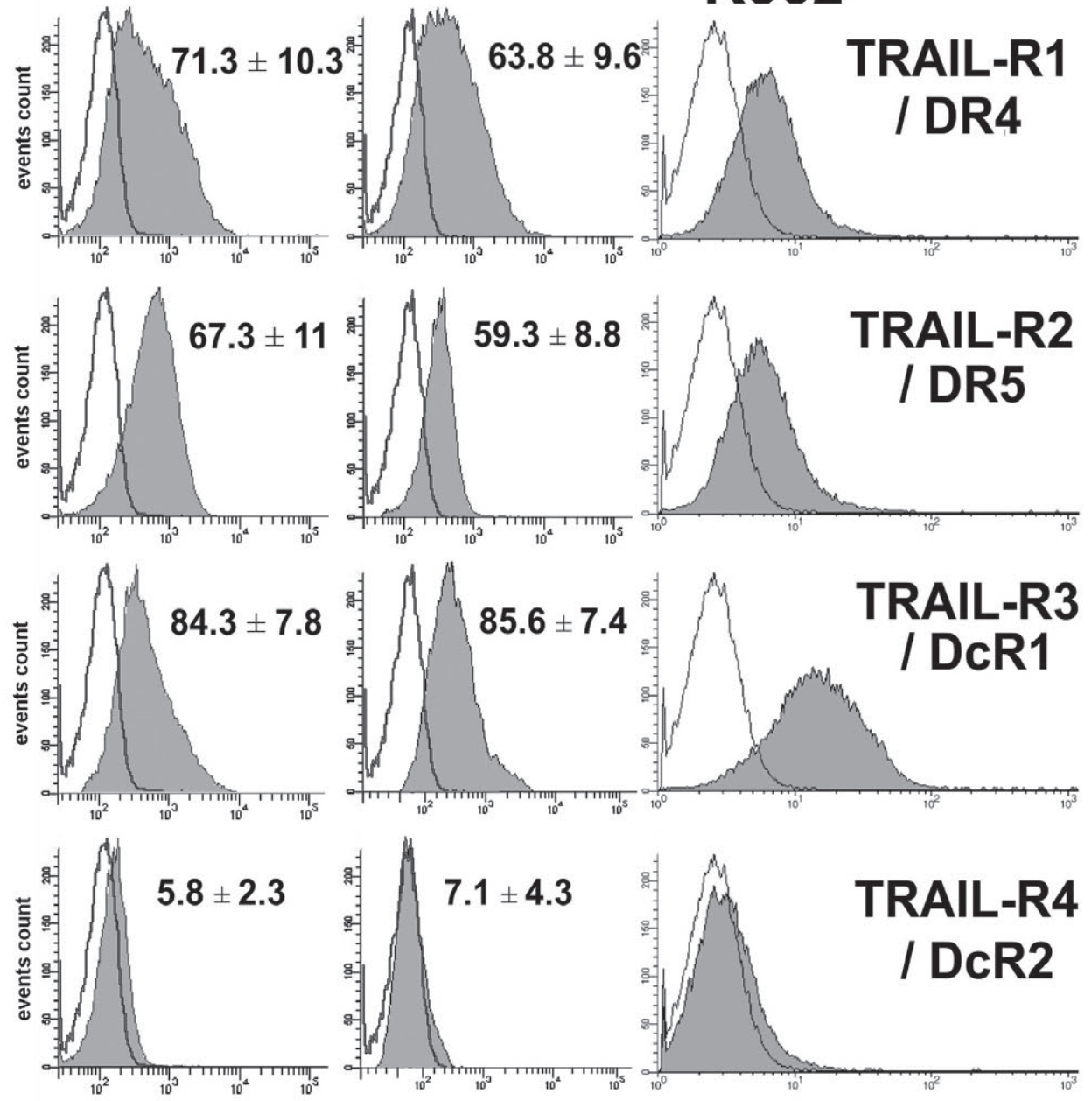

Figure 1. A. Primary AML $(n=5)$ and CML $(n=5)$ cells are inherently resistant to TRAIL-induced apoptosis. Percentage of Annexin-V-positive cells was analyzed by flow cytometry 24 hours after exposure of the cells to TRAIL $(1000 \mathrm{ng} / \mathrm{ml})$. The histograms indicate representative examples of each group (AML, $\mathrm{CML}$ ), and numbers represent means \pm SDs of the percentages of apoptotic cells calculated from the entire groups (AML, CML). Specifically, the numbers represent differences between the TRAIL-exposed and TRAIL-unexposed cells. B. Flow cytometry analysis of cell surface expression of TRAIL receptors 1-4 on primary AML cells ( $n=5)$, CML cells (n=5) and K562 cell line (K562). The histograms indicate representative examples of each group (AML, CML, K562). Full histograms are stains with primary and secondary antibodies, while open histograms correspond to the control stains of the cells with secondary antibody only. The numbers represent diffences between the mean fluorescence intensities (MFIs) \pm SDs calculated for stains with primary and secondary antibodies, and MFIs calculated for stains with secondary antibodies only. C. S1 and S2 K562 clones are more sensitive to TRAIL and TNF-alpha compared to the original K562 cell line. The percentage of Annexin-V-positive cells 24 hours after exposure to TRAIL (1000 ng/ml) and TNF-alpha (100 ng/ml) was measured using flow cytometry. Columns represent mean percentages of Annexin-V-positive apoptotic cells of untreated cells (open columns), cells after the exposure to TRAIL (black columns), and TNF-alpha (checkered columns). Error bars represent standard deviations of two independent experiments. The treatment with TRAIL and TNF-alpha induced significantly greater apoptosis of $\mathrm{S} 1(\mathrm{p}<0.01)$ and $\mathrm{S} 2(\mathrm{p}<0.01)$ clones compared to similarly treated original $\mathrm{K} 562$ cells. The background apoptosis of untreated S1, S2, and original K562 cells was not significantly different. 
K562
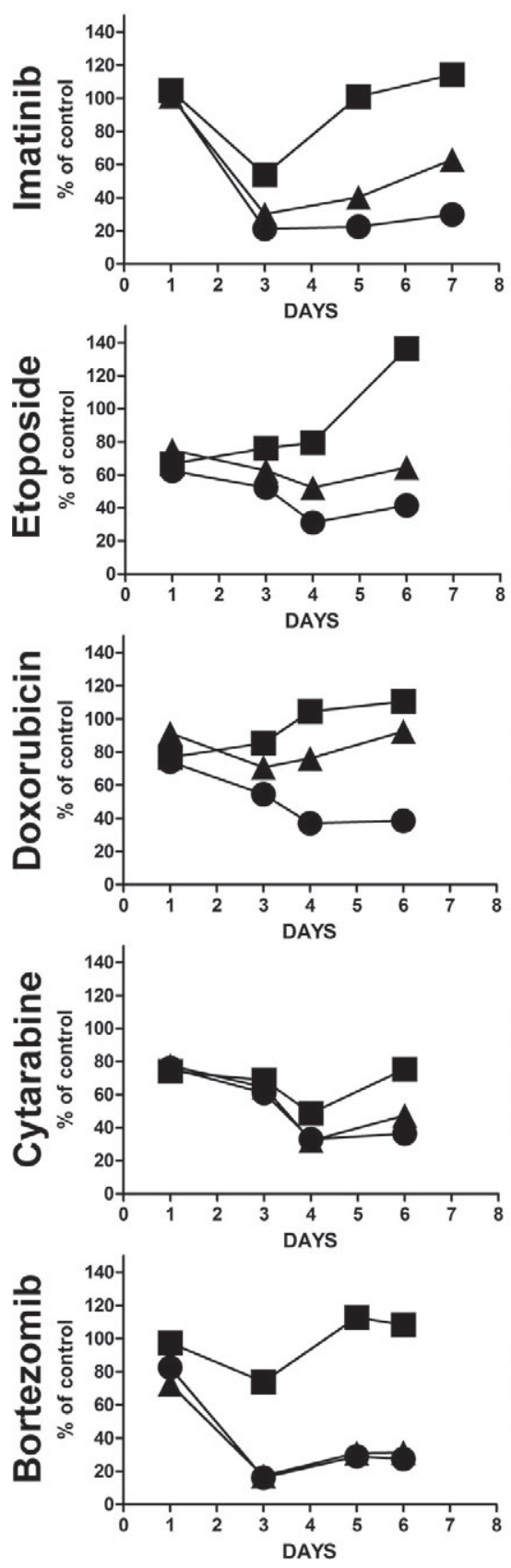

S1
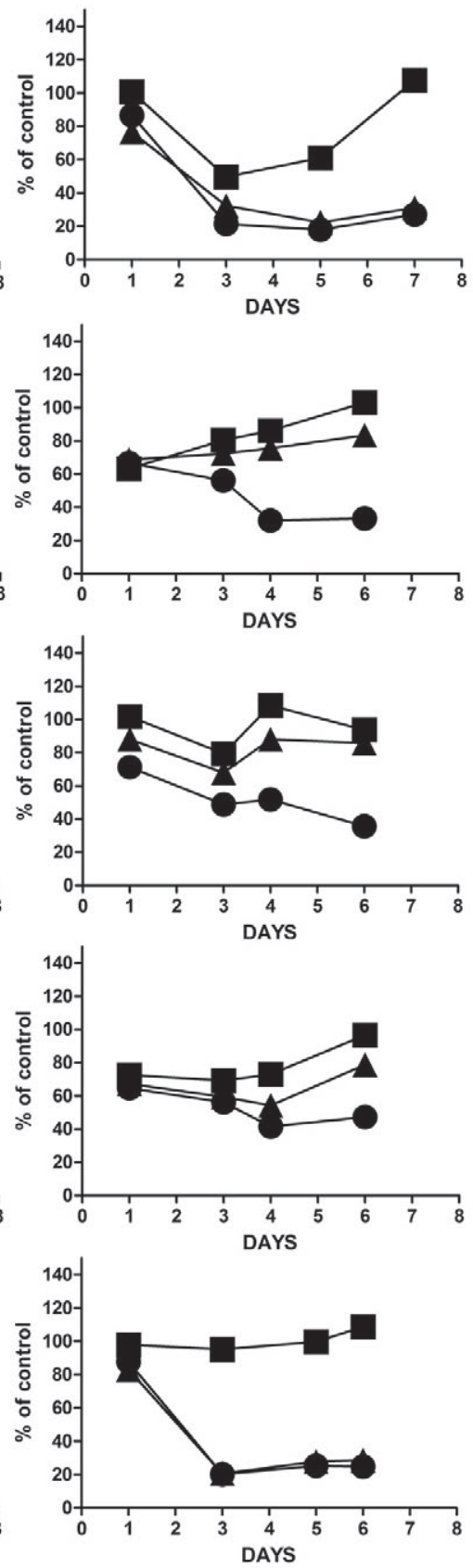

S2
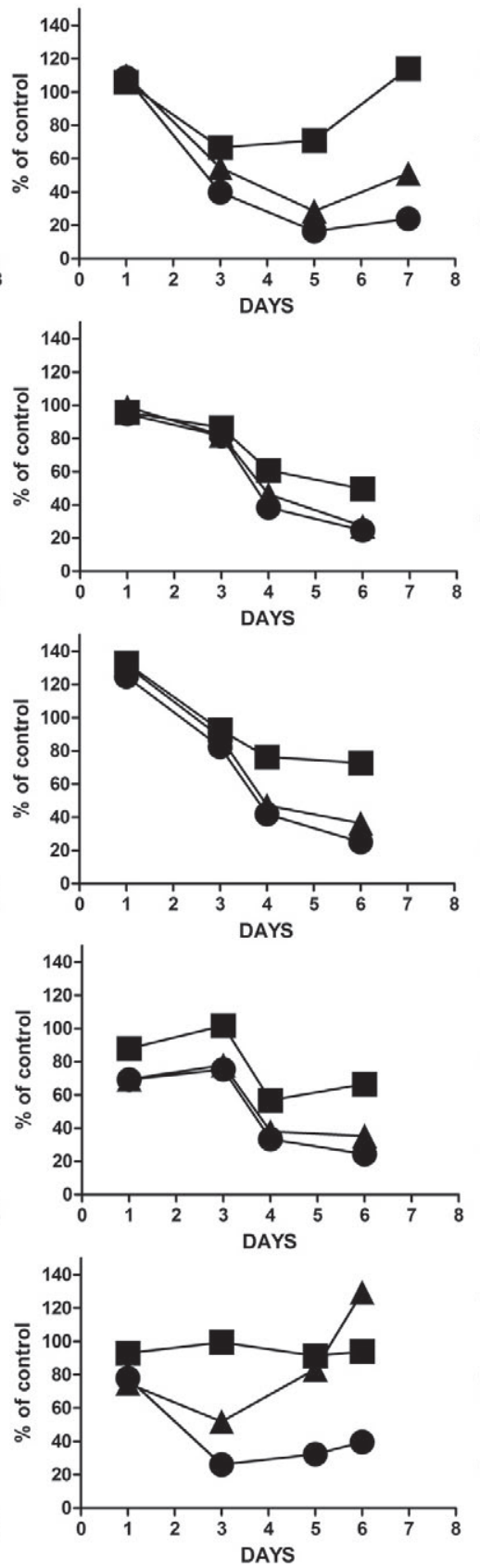

$100 \mathrm{nM}$

$200 \mathrm{nM}$

$400 \mathrm{nM}$

$80 \mathrm{nM}$

$160 \mathrm{nM}$

$640 \mathrm{nM}$

$4 \mathrm{nM}$

$8 \mathrm{nM}$

$32 \mathrm{nM}$

$120 \mathrm{nM}$

$240 \mathrm{nM}$

$480 \mathrm{nM}$

$5 \mathrm{nM}$

$10 \mathrm{nM}$

$20 \mathrm{nM}$

Figure 2. A. K562 cells and TRAIL-sensitive clones S1 and S2 are sensitive to selected anti-tumor drugs. WST-8-based cell-proliferation assay was used to assess impact of the cytotoxic agents on proliferation rate. Measurements were performed in triplicates over several days (X axis). On $\mathrm{Y}$ axis, ratios between the drug-exposed and unexposed cells are shown (“\% control”).

26kDa, mouse (1:1000), Survivin (3161-100), BioVision, 17 $\mathrm{kDa}$, rabbit (1:1000).

Statistical analysis. Student's t-test was applied to evaluate statistical significance of the observed differences between TNF-alpha- and TRAIL-induced apoptosis in TRAIL-sensitive clones S1 and S2 compared to the original K562 cell line.

\section{Results}

Primary AML and CML blasts express TRAIL receptors 1-3, and are inherently resistant to TRAIL-induced apoptosis. We analyzed proapoptotic activity of TRAIL using peripheral blood mononuclear cells obtained from 
patients with newly diagnosed acute myeloid leukemia (AML, $\mathrm{n}=5$ ) and chronic myeloid leukemia (CML, $\mathrm{n}=5$ ). We confirmed that all primary AML and CML blasts were indeed resistant to TRAIL-induced apoptosis showing less than $10 \%$ apoptosis after 24 hour exposure to $1000 \mathrm{ng} / \mathrm{mL}$ TRAIL (Fig. 1a). We also demonstrated that the primary AML/CML blasts expressed both TRAIL death-receptors (TRAIL-R1/DR4 and TRAIL-R2/DR5), as well as the decoy receptor 1 (TRAIL-R3/DcR1), but not the decoy receptor 2 (TRAIL-R4/DcR2) (Fig. 1b).

TRAIL-sensitive K562 clones S1 and S2 show increased sensitivity to TNF-alpha, but not to cytotoxic agents imatinib, cytarabine, etoposide, doxorubicin, and bortezomib. To analyze the molecular basis of the observed TRAIL-resistance of myeloid leukemia blasts, we used K562 cell line, established from a patient with erythroleukemia progressed from CML, which is characterized by TRAIL-resistance and similar pattern of expression of TRAIL receptors compared to primary AML/CML blasts (Fig. 1b, 1c). By limiting dilution approach we derived two TRAIL-sensitive K562 clones designated $\mathrm{S} 1$ and $\mathrm{S} 2$. In concordance with our previous study on HL60 cells [37] we demonstrated that the TRAIL-sensitive clones S1 and S2 were also more sensitive to TNF-alpha compared to the original K562 cell line (Fig. 1c), but have retained sensitivity to selected anti-tumor agents imatinib, cytarabine, etoposide, doxorubicin or bortezomib (Fig. 2).

TRAIL-sensitive K562 clones show marked cell surface downregulation of decoy receptor 1 , slight upregulation of both death receptors, and increased recruitment and cleavage of CASP8 at the DISC after exposure to TRAIL. Flow cytometry analysis of TRAIL-sensitive clones S1 and S2 revealed marked downregulation of the cell surface decoy receptor 1 , and slight upregulation of both TRAIL death receptors, while expression of both TNF receptors remained unchanged (Fig. 3a). Analysis of death-inducing signaling complex (DISC) revealed comparable amounts of precipitated TRAIL-receptor 2 (DR5) in TRAIL-resistant K562 cells and TRAIL-sensitive clones S1 and S2 after exposure to biotinylated TRAIL (at all time-points) (Fig. 3b). S1 and $\mathrm{S} 2$ clones, however, showed markedly increased binding of CASP8 to the DISC (at 0 minutes), as well as enhanced cleavage of CASP8 at 10 and 30 minutes after exposure to biotinylated TRAIL (Fig. 3b). As the amounts of cleaved FLIP-L at 10 and 30 minutes appeared similar in all tested samples, CASP8 to FLIP ratio was significantly increased in TRAIL sensitive clones compared to the original K562 cell line (Fig. 3b).

TRAIL-sensitive K562 clones show increased protein expression of several key proapoptotic BCL2 family members. In our recently published study by Molinsky et al. (20) we demonstrated that downregulation of antiapoptotic BCL2 molecules MCL1 and BCL-XL strongly sensitized K562 cells to TRAIL-induced apoptosis. We thus decided to analyze expression profile of key BCL2 members and other selected apoptosis regulators in TRAIL-sensitive K562 clones com-
A.

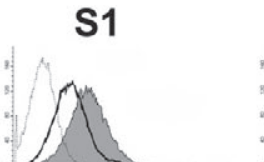

S2

TRAIL-R1/DR4
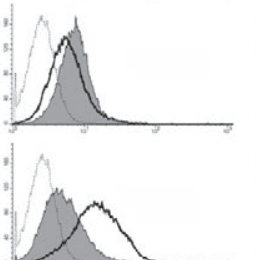

TRAIL-R2/DR5
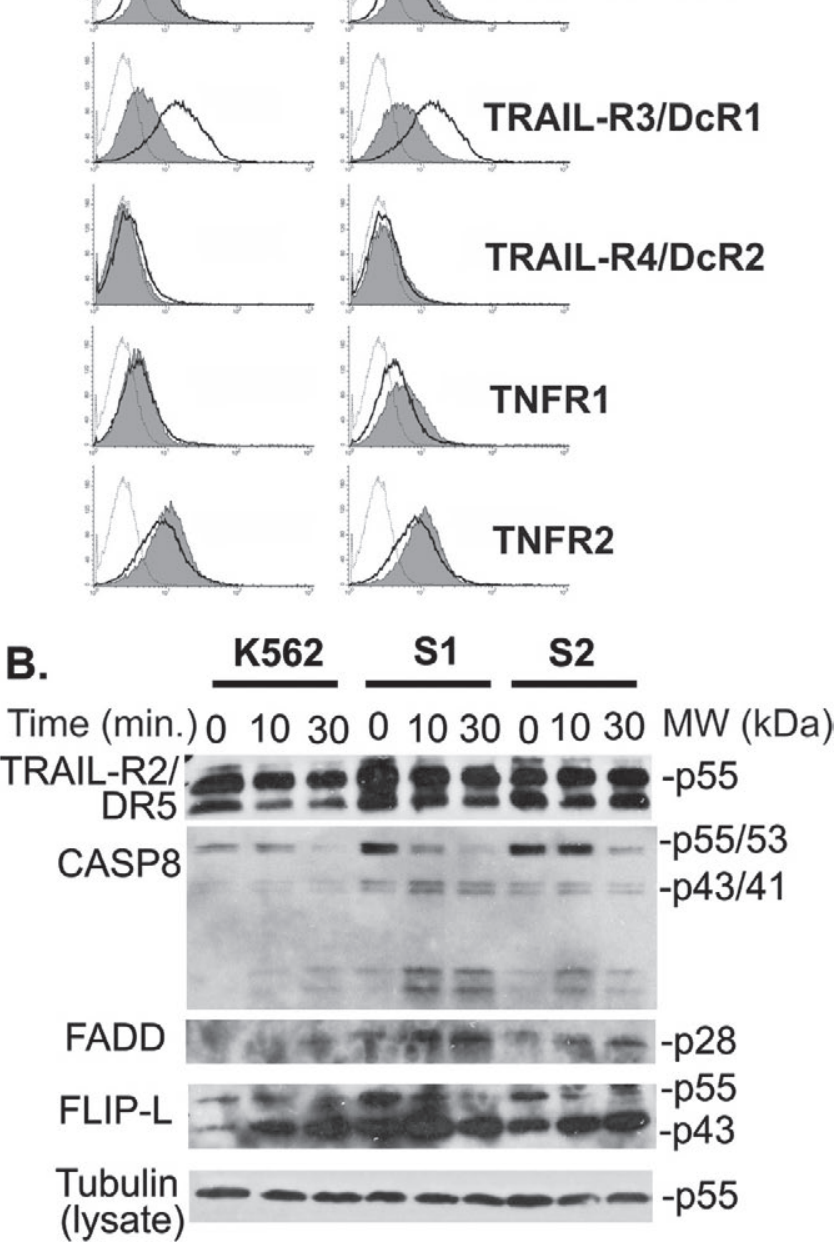

Figure 3. A. Flow cytometry analysis of cell surface expression of TRAIL and TNF receptors on TRAIL-sensitive K562 clones S1 and S2 (full histograms) compared to the original TRAIL-resistant K562 cell line (thick open histograms). Open thin histograms represent cells stained with secondary antibody only. B. Analysis of death-inducing signaling complex (DISC) by precipitation with biotinylated TRAIL. Tubulin immunoblots from whole cell lysates (placed at the bottom) were used as a control of protein load.

pared to TRAIL-resistant K562 cell line by western blotting. In both TRAIL-sensitive clones we found protein upregulation of proapoptotic proteins CASP8, BAD, BID, BIM, BAK, and upregulation of antiapoptotic BCL-XL (Fig. 4). Downregulation of BCL2 and upregulation of XIAP was detected in clone S1, while downregulation of MCL1 was detected in S2 clone (Fig. 4). 


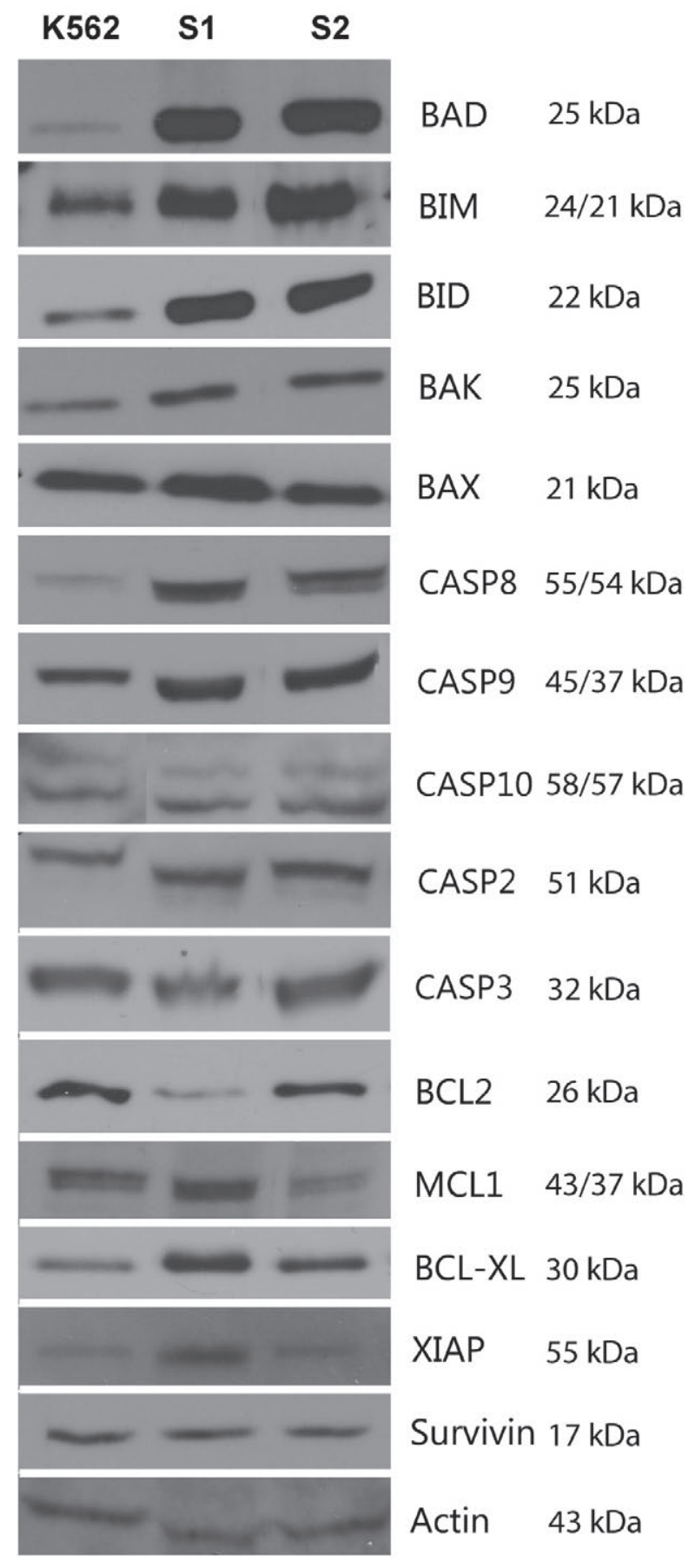

Figure 4. Western blot analysis of whole cell lysates of TRAIL-sensitive K562 clones (S1, S2) and the original K562 cell line (K562). Western blots were performed as described in Materials and Methods. Beta-actin immunoblots were used as a control of protein load.

\section{Discussion}

Up to the present time a wide array of molecules and signaling pathways were reported as pivotal players mediating
TRAIL-resistance of leukemia cells $[6,35,37,38]$. In this study we analyzed molecular mechanisms responsible for TRAILresistance of K562 cell line and the nature of TRAIL-sensitivity of two TRAIL-sensitive K562 clones (S1, S2) established by limiting-dilution approach from the original K562 cell line. Both TRAIL-sensitive K562 clones showed almost identical molecular changes compared to the original K562 cells, namely 1. marked downregulation of the decoy receptor 1 together with slight upregulation of both death receptors, 2 . increased expression of cytosolic CASP8, enhanced recruitment of CASP8 to the DISC, and increased cleavage of CASP8 at the DISC, and 3. protein overexpression of key proapoptotic BCL2 members BID, BAD, BIM, and BAK, together with upregulation of BCL-XL (Fig. 3-4). Each of these molecular changes, with the exception of BCL-XL, might contribute to the observed enhanced sensitivity of S1 and S2 clones to TRAIL. The molecular differences between TRAIL-resistant and TRAIL-sensitive K562 cells thus appeared to involve the extrinsic apoptotic pathway at three different levels: 1 . the receptor level, 2. the DISC level, and 3. the mitochondria level.

Despite the fact that the precise role of the decoy receptors 1 and 2 in TRAIL-triggered apoptosis remains incompletely understood, most studies published so far supported their role in mediating TRAIL-resistance $[9,10,10,29,30,39-44]$. In this study, we observed cell surface downregulation of the decoy receptor 1 in both TRAIL-sensitive clones (Fig. 3a). Surprisingly, analysis of the DISC after exposure to biotinylated TRAIL revealed that the amounts of precipitated death receptor 5 were comparable in TRAIL-resistant and TRAIL-sensitive K562 cells (Fig. 3b). Recruitments of other key DISC components CASP8, FADD and FLIP, however, displayed significantly decreased levels in TRAIL-resistant K562 cells (Fig. 3b). While cleavage of CASP8 was significantly decreased in TRAILresistant K562 cells, the amounts of cleaved FLIP-L appeared similar in all analyzed samples (Fig. 3b). We thus assume that the generation of large amounts of cleaved FLIP-L together with small amounts of cleaved CASP8 led to the functional blockage of propagation of apoptotic signal from the ligated TRAILR2/DR5 in K562 cell line.

In our previous study by Molinsky et al. [20] we demonstrated that targeted downregulation of a single anti-apoptotic protein MCL1 or BCL-XL, but not BCL2, was sufficient to fully sensitize K562 cells to TRAIL. We also showed that pretreatment with BH3-mimetic agent ABT-737 sensitized K562 cells to TRAIL. In this current study we reported significant upregulation of key proapoptotic BCL2 family proteins BID, BAD, BIM and BAK in TRAIL-sensitive K562 clones compared to TRAIL-resistant K562 cells (Fig. 4). We assume that the consequences of either MCL1/BCL-XL downregulation/sequestration or BID/BAD/BIM/BAK upregulation are similar in that these molecular events induce permissive state of TRAILsensitivity by effectively amplifying proapoptotic signals from the TRAIL-ligated death receptors via the mitochondria. Based on the results of both our studies we suppose that changed expressions of BCL2 family members represent major molecular 
events that mediate TRAIL-sensitivity of K562 clones, while overexpression of cytoplasmic CASP8 and downregulation of cell surface decoy receptor 1 might contribute to the extent of TRAIL-sensitivity. We suppose that the increased DISC assembly and enhanced cleavage of CASP8 represent direct consequences of the changed expression of BCL2 proteins, CASP8 and DcR1.

In concordance with our previous study by Klener et al. [37], restoration of the extrinsic apoptotic cascade in TRAILsensitive clones S1 and S2 was associated with increased sensitivity to TNF-alpha, another important proapoptotic cytokine (Fig. 1c). In contrast, susceptibility of the clones remained unchanged to all of the tested anti-tumor drugs including imatinib (targeted agent: inhibitor of BCR-ABL tyrosine kinase), cytarabine (genotoxic agent: antinucleotide), etoposide (genotoxic agent: inhibitor of topoisomerase), doxorubicin (genotoxic agent: intercalating agent) and bortezomib (targeted agent: inhibitor of proteasome) (Fig. 2). The reason, why the observed proapoptotic changes in the protein expression of several key BCL2 molecules were not associated with increased sensitivity to tested cytotoxic or targeted agents remains a conundrum. In the study by Molinsky et al. [20] we demonstrated that roscovitine, a cyclin-dependent kinase inhibitor, sensitized K562 cells (as well as primary AML/CML blasts) to TRAIL-induced apoptosis, and that this sensitization was associated with changed profile of BCL2 proteins. Despite the fact that pretreatment with roscovitine restored sensitivity of K562 cells to TRAIL and TNF-alpha, it did not increase sensitivity of the cells to commonly used cytotoxic agents. This finding was very similar compared to the results observed in this report. Precise molecular mechanisms, by which changed profile of BCL2 proteins at the mitochondria might selectively augment receptor-triggered apoptosis, remain to be elucidated.

In conclusion, inherent TRAIL-resistance of K562 cells (and potentially of AML and CML blasts) appears a consequence of multi-level disruption of the extrinsic apoptotic pathway. The results of this study also suggest that the leukemia TRAILresistance is functional (not structural), leaving a possibility of overcoming the resistance by preexposure of the leukemia cells to potent TRAIL sensitizers, e.g. BH3-mimetics.

Acknowledgements: Financial Support: GAUK 259153/86309, PRVOUK P24/LF1/3, UNCE 204021, SVV-2012-254260507. Special thanks to Monika Hulova.

\section{References}

[1] WILEY SR, SCHOOLEY K, SMOLAK PJ, DIN WS, HUANG $\mathrm{CP}$ et al. Identification and characterization of a new member of the TNF family that induces apoptosis. Immunity 1995; 3 : 673-682. http://dx.doi.org/10.1016/1074-7613(95)90057-8

[2] SHERIDAN JP, MARSTERS SA, PITTI RM, GURNEY A, SKUBATCH M et al. Control of TRAIL-induced apoptosis by a family of signaling and decoy receptors.
Science 1997; 277: 818-821. http://dx.doi.org/10.1126/ science.277.5327.818

[3] PITTI RM, MARSTERS SA, RUPPERT S, DONAHUE CJ, MOORE A et al. Induction of apoptosis by Apo-2 ligand, a new member of the tumor necrosis factor cytokine family. J Biol Chem 1996; 271: 12687-12690. http://dx.doi.org/10.1074/ jbc.271.22.12687

[4] PORDZIK S, PETROVICI K, SCHMID C, KROELL T, SCHWEIGER $\mathrm{C}$ et al. Expression and prognostic value of FAS receptor/FAS ligand and TrailR1/TrailR2 in acute myeloid leukemia. Hematology 2011; 16: 341-350. http://dx.doi. org/10.1179/102453311X13127324303353

[5] LI Y, JIN X, LI J, JIN X, YU J et al. Expression of TRAIL, DR4, and DR5 in bladder cancer: correlation with response to adjuvant therapy and implications of prognosis. Urology 2012; 79: 968-15. http://dx.doi.org/10.1016/j.urology.2011.11.011

[6] CHAMULEAU ME, OSSENKOPPELE GJ, VAN RHENEN A, VAN DREUNEN L, JIRKA SM et al. High TRAIL-R3 expression on leukemic blasts is associated with poor outcome and induces apoptosis-resistance which can be overcome by targeting TRAIL-R2. Leuk Res 2011; 35: 741-749. http://dx.doi. org/10.1016/j.leukres.2010.12.032

[7] MCLORNAN DP, BARRETT HL, CUMMINS R, MCDERMOTT U, MCDOWELL C et al. Prognostic significance of TRAIL signaling molecules in stage II and III colorectal cancer. Clin Cancer Res 2010; 16: 3442-3451. http://dx.doi. org/10.1158/1078-0432.CCR-10-0052

[8] MACHER-GOEPPINGER S, AULMANN S, TAGSCHERER KE, WAGENER N, HAFERKAMP A et al. Prognostic value of tumor necrosis factor-related apoptosis-inducing ligand (TRAIL) and TRAIL receptors in renal cell cancer. Clin Cancer Res 2009; 15: 650-659. http://dx.doi.org/10.1158/1078-0432. CCR-08-0284

[9] GRANCI V, BIBEAU F, KRAMAR A, BOISSIERE-MICHOT F, THEZENAS $S$ et al. Prognostic significance of TRAIL-R1 and TRAIL-R3 expression in metastatic colorectal carcinomas. Eur J Cancer 2008; 44: 2312-2318. http://dx.doi.org/10.1016/ j.ejca.2008.06.042

[10] KOKSAL IT, SANLIOGLU AD, KARACAY B, GRIFFITH TS, SANLIOGLU S. Tumor necrosis factor-related apoptosis inducing ligand-R4 decoy receptor expression is correlated with high Gleason scores, prostate-specific antigen recurrence, and decreased survival in patients with prostate carcinoma. Urol Oncol 2008; 26: 158-165. http://dx.doi.org/10.1016/ j.urolonc.2007.01.022

[11] VAN GEELEN CM, WESTRA JL, DE VRIES EG, BOERSMAVAN EK W, ZWART N et al. Prognostic significance of tumor necrosis factor-related apoptosis-inducing ligand and its receptors in adjuvantly treated stage III colon cancer patients. J Clin Oncol 2006; 24: 4998-5004. http://dx.doi.org/10.1200/ JCO.2006.06.8809

[12] ZHUANG L, LEE CS, SCOLYER RA, MCCARTHY SW, ZHANG XD et al. Progression in melanoma is associated with decreased expression of death receptors for tumor necrosis factor-related apoptosis-inducing ligand. Hum Pathol 2006; 37: 1286-1294. http://dx.doi.org/10.1016/ j.humpath.2006.04.026 
[13] KUIJLEN JM, MOOIJ JJ, PLATTEEL I, HOVING EW, VAN DER GRAAF WT et al. TRAIL-receptor expression is an independent prognostic factor for survival in patients with a primary glioblastoma multiforme. J Neurooncol 2006; 78: 161-171. http://dx.doi.org/10.1007/s11060-005-9081-1

[14] ASHKENAZI A, HOLLAND P, ECKHARDT SG. Ligandbased targeting of apoptosis in cancer: the potential of recombinant human apoptosis ligand 2/Tumor necrosis factor-related apoptosis-inducing ligand (rhApo2L/TRAIL). J Clin Oncol 2008; 26: 3621-3630. http://dx.doi.org/10.1200/ LCO.2007.15.7198

[15] HERBST RS, ECKHARDT SG, KURZROCK R, EBBINGHAUS S, O'DWYER PJ et al. Phase I dose-escalation study of recombinant human Apo2L/TRAIL, a dual proapoptotic receptor agonist, in patients with advanced cancer. J Clin Oncol 2010; 28: 2839-2846. http://dx.doi.org/10.1200/JCO.2009.25.1991

[16] HOTTE SJ, HIRTE HW, CHEN EX, SIU LL, LE LH et al. A phase 1 study of mapatumumab (fully human monoclonal antibody to TRAIL-R1) in patients with advanced solid malignancies. Clin Cancer Res 2008; 14:3450-3455. http://dx.doi. org/10.1158/1078-0432.CCR-07-1416

[17] SORIA JC, SMIT E, KHAYAT D, BESSE B, YANG X et al. Phase 1b study of dulanermin (recombinant human Apo2L/ TRAIL) in combination with paclitaxel, carboplatin, and bevacizumab in patients with advanced non-squamous nonsmall-cell lung cancer. J Clin Oncol 2010; 28: 1527-1533. http://dx.doi.org/10.1200/JCO.2009.25.4847

[18] LEONG S, COHEN RB, GUSTAFSON DL, LANGER CJ, CAMIDGE DR et al. Mapatumumab, an antibody targeting TRAIL-R1, in combination with paclitaxel and carboplatin in patients with advanced solid malignancies: results of a phase I and pharmacokinetic study. J Clin Oncol 2009; 27: 4413-4421. http://dx.doi.org/10.1200/JCO.2008.21.7422

[19] LU X, ARBISER JL, WEST J, HOEDT-MILLER M, SHERIDAN A et al. Tumor necrosis factor-related apoptosis-inducing ligand can induce apoptosis in subsets of premalignant cells. Am J Pathol 2004; 165: 1613-1620. http://dx.doi.org/10.1016/S0002-9440(10)63418-9

[20] MOLINSKY J, KLANOVA M, KOC M, BERANOVA L, ANDERA $L$ et al. Roscovitine sensitizes leukemia and lymphoma cells to tumor necrosis factor-related apoptosis-inducing ligand-induced apoptosis. Leuk Lymphoma 2012. http://dx.doi. org $/ 10.3109 / 10428194.2012 .710331$

[21] KIM HB, KIM MJ, KIM DY, LEE JW, BAE JH et al. High susceptibility of metastatic cells derived from human prostate and colon cancer cells to TRAIL and sensitization of TRAIL-insensitive primary cells to TRAIL by 4,5-dimethoxy2-nitrobenzaldehyde. Mol Cancer 2011; 10: 46. http://dx.doi. org/10.1186/1476-4598-10-46

[22] FRENZEL LP, PATZ M, PALLASCH CP, BRINKER R, CLAASEN J et al. Novel X-linked inhibitor of apoptosis inhibiting compound as sensitizer for TRAIL-mediated apoptosis in chronic lymphocytic leukaemia with poor prognosis. $\mathrm{Br}$ J Haematol 2011; 152: 191-200. http://dx.doi.org/10.1111/ j.1365-2141.2010.08426.x

[23] CARTER BZ, MAK DH, SCHOBER WD, DIETRICH MF, PINILLA C et al. Triptolide sensitizes AML cells to TRAIL- induced apoptosis via decrease of XIAP and p53-mediated increase of DR5. Blood 2008; 111: 3742-3750. http://dx.doi. org/10.1182/blood-2007-05-091504

[24] KIM YH, PARK JW, LEE JY, KWON TK. Sodium butyrate sensitizes TRAIL-mediated apoptosis by induction of transcription from the DR5 gene promoter through Sp1 sites in colon cancer cells. Carcinogenesis 2004; 25: 1813-1820. http://dx.doi.org/10.1093/carcin/bgh188

[25] FULDA S, DEBATIN KM. Sensitization for tumor necrosis factor-related apoptosis-inducing ligand-induced apoptosis by the chemopreventive agent resveratrol. Cancer Res 2004; 64: 337-346. http://dx.doi.org/10.1158/0008-5472.CAN-03$\underline{1656}$

[26] HU L, CAO D, LI Y, HE Y, GUO K. Resveratrol sensitized leukemia stem cell-like KG-1a cells to cytokine-induced killer cells-mediated cytolysis through NKG2D ligands and TRAIL receptors. Cancer Biol Ther 2012; 13: 516-526. http://dx.doi. org/10.4161/cbt.19601

[27] ALLEN JE, FERRINI R, DICKER DT, BATZER G, CHEN E et al. Targeting TRAIL death receptor 4 with trivalent DR4 Atrimer complexes. Mol Cancer Ther 2012. http://dx.doi. org/10.1158/1535-7163.MCT-12-0366

[28] TUR V, VAN DER SLOOT AM, REIS CR, SZEGEZDI E, COOL RH et al. DR4-selective tumor necrosis factor-related apoptosis-inducing ligand (TRAIL) variants obtained by structure-based design. J Biol Chem 2008; 283: 20560-20568. http://dx.doi.org/10.1074/jbc.M800457200

[29] RICCIONI R, PASQUINI L, MARIANI G, SAULLE E, ROSSINI A et al. TRAIL decoy receptors mediate resistance of acute myeloid leukemia cells to TRAIL. Haematologica 2005; 90: 612-624.

[30] CHAMULEAU ME, OSSENKOPPELE GJ, VAN RHENEN A, VAN DREUNEN L, JIRKA SM et al. High TRAIL-R3 expression on leukemic blasts is associated with poor outcome and induces apoptosis-resistance which can be overcome by targeting TRAIL-R2. Leuk Res 2011; 35: 741-749. http://dx.doi. org/10.1016/j.leukres.2010.12.032

[31] SEAL S, HOCKENBERY DM, SPAULDING EY, KIEM HP, ABBASSI $\mathrm{N}$ et al. Differential responses of FLIPLong and FLIPShort-overexpressing human myeloid leukemia cells to TNF-alpha and TRAIL-initiated apoptotic signals. Exp Hematol 2008; 36: 1660-1672. http://dx.doi.org/10.1016/ j.exphem.2008.07.012

[32] GUO F, SIGUA C, BALI P, GEORGE P, FISKUS $\mathrm{W}$ et al. Mechanistic role of heat shock protein 70 in Bcr-Abl-mediated resistance to apoptosis in human acute leukemia cells. Blood 2005; 105: 1246-1255. http://dx.doi.org/10.1182/blood-2004$\underline{05-2041}$

[33] DIDA F, LI Y, IWAO A, DEGUCHI T, AZUMA E et al. Resistance to TRAIL-induced apoptosis caused by constitutional phosphorylation of Akt and PTEN in acute lymphoblastic leukemia cells. Exp Hematol 2008; 36: 1343-1353. http:// dx.doi.org/10.1016/j.exphem.2008.04.011

[34] INUKAI T, ZHANG X, GOTO M, HIROSE K, UNO K et al. Resistance of infant leukemia with MLL rearrangement to tumor necrosis factor-related apoptosis-inducing ligand: a possible mechanism for poor sensitivity to antitumor 
immunity. Leukemia 2006; 20: 2119-2129. http://dx.doi. org/10.1038/sj.leu.2404429

[35] CHENG J, HYLANDER BL, BAER MR, CHEN X, REPASKY EA. Multiple mechanisms underlie resistance of leukemia cells to Apo2 Ligand/TRAIL. Mol Cancer Ther 2006; 5: 1844-1853. http://dx.doi.org/10.1158/1535-7163.MCT-06-0050

[36] HAO XS, HAO JH, LIU FT, NEWLAND AC, JIA L. Potential mechanisms of leukemia cell resistance to TRAIL-induced apopotosis. Apoptosis 2003; 8: 601-607. http://dx.doi. org/10.1023/A:1026131425204

[37] KLENER P, JR., LEAHOMSCHI S, MOLINSKY J, SIMONOVA T, NECAS E et al. TRAIL-induced apoptosis of HL60 leukemia cells: two distinct phenotypes of acquired TRAIL resistance that are accompanied with resistance to TNFalpha but not to idarubicin and cytarabine. Blood Cells Mol Dis 2009; 42: 77-84. http://dx.doi.org/10.1016/j.bcmd.2008.10.002

[38] AKAHANE K, INUKAI T, ZHANG X, HIROSE K, KURODA I et al. Resistance of T-cell acute lymphoblastic leukemia to tumor necrosis factor--related apoptosis-inducing ligand-mediated apoptosis. Exp Hematol 2010; 38: 885-895. http://dx.doi.org/10.1016/j.exphem.2010.06.014

[39] DELIGEZER U, DALAY N. Expression of the TRAIL receptors in blood mononuclear cells in leukemia. Pathol Oncol Res 2007; 13: 290-294. http://dx.doi.org/10.1007/BF02940307
[40] VINDRIEUX D, REVEILLER M, CHANTEPIE J, YAKOUB $\mathrm{S}$, DESCHILDRE C et al. Down-regulation of DcR2 sensitizes androgen-dependent prostate cancer LNCaP cells to TRAILinduced apoptosis. Cancer Cell Int 2011; 11: 42. http://dx.doi. org/10.1186/1475-2867-11-42

[41] LALAOUI N, MORLE A, MERINO D, JACQUEMIN G, IESSI E et al. TRAIL-R4 promotes tumor growth and resistance to apoptosis in cervical carcinoma HeLa cells through AKT. PLoS One 2011; 6: e19679. http://dx.doi.org/10.1371/journal. pone.0019679

[42] ZHU DM, SHI J, LIU S, LIU Y, ZHENG D. HIV infection enhances TRAIL-induced cell death in macrophage by down-regulating decoy receptor expression and generation of reactive oxygen species. PLoS One 2011; 6: e18291. http:// dx.doi.org/10.1371/journal.pone.0018291

[43] MORIZOT A, MERINO D, LALAOUI N, JACQUEMIN G, GRANCI V et al. Chemotherapy overcomes TRAIL-R4-mediated TRAIL resistance at the DISC level. Cell Death Differ 2011; 18: 700-711. http://dx.doi.org/10.1038/cdd.2010.144

[44] TOSCANO F, FAJOUI ZE, GAY F, LALAOUI N, PARMENTIER B et al. P53-mediated upregulation of DcR1 impairs oxaliplatin/TRAIL-induced synergistic anti-tumour potential in colon cancer cells. Oncogene 2008; 27: 4161-4171. http:// dx.doi.org/10.1038/onc.2008.52 